\title{
Additional Collections of Woodland to Caddo Period Artifacts from the Alligator Pond Site (41SM442), Smith County, Texas
}

Timothy K. Perttula

Heritage Research Center, Stephen F. Austin State University

Mark Thacker

Follow this and additional works at: https://scholarworks.sfasu.edu/ita

Part of the American Material Culture Commons, Archaeological Anthropology Commons, Environmental Studies Commons, Other American Studies Commons, Other Arts and Humanities Commons, Other History of Art, Architecture, and Archaeology Commons, and the United States History Commons

Tell us how this article helped you.

This Article is brought to you for free and open access by the Center for Regional Heritage Research at SFA ScholarWorks. It has been accepted for inclusion in Index of Texas Archaeology: Open Access Gray Literature from the Lone Star State by an authorized editor of SFA ScholarWorks. For more information, please contact cdsscholarworks@sfasu.edu. 
Additional Collections of Woodland to Caddo Period Artifacts from the Alligator Pond Site (41SM442), Smith County, Texas

\section{Creative Commons License}

\section{(c) (1) (8)}

This work is licensed under a Creative Commons Attribution-NonCommercial 4.0 International License 


\title{
Additional Collections of Woodland to Caddo Period Artifacts from the Alligator Pond Site (41SM442), Smith County, Texas
}

\author{
Timothy K. Perttula and Mark Thacker
}

\section{INTRODUCTION}

The Alligator Pond site is a substantial multi-component prehistoric and historic archaeological site (ca. 1.5 acres) on an upland ridge on the east side of Saline Creek. Saline Creek is a northward-flowing tributary to the Sabine River, and the site is ca. $10 \mathrm{~km}$ south of the confluence of Saline Creek with the Sabine River, in the Post Oak Savannah in northern Smith County, Texas.

This is the third article that reports on the artifact assemblages from the site (see Perttula and Thacker 2013; Perttula and Walters 2012). Previous analyses of the artifact assemblages indicate that the principal component is a pre-A.D. 1200 Caddo habitation site, but there is also evidence from temporally diagnostic ceramic sherds and dart points that the site was used to some extent during the Woodland (ca. 500 B.C.-A.D. 800), Late Archaic (ca. 3000-500 B.C.), and Middle Archaic (ca. 6000-3000 B.C.) periods. Finally, there is an early $19^{\text {th }}$ century historic component at the Alligator Pond site that is marked by blade gunflints, glass seed beads, refined earthenware rim and body sherds, possibly pearlware, that have hand-painted floral decorations, and an alkaline-glazed stoneware crock sherd.

\section{CERAMIC ARTIFACTS}

There are at present a total of 2587 sherds from the ancestral Caddo occupation at the Alligator Pond site (Table 1), about $85.5 \%$ of which are plain rim, body, and base sherds. Based on the 66 rim sherds in the assemblage, $48 \%$ of the vessels are likely plain vessels, another $44 \%$ are from utility ware jars, and $8 \%$ are from fine ware bowls and carinated bowls. The plain to decorated sherd ratio is 5.88 . Approximately $92.5 \%$ of the sherds are tempered with grog (and crushed hematite pieces), and the remainder have burned bone temper.

More than $70 \%$ of the decorated sherds from the Alligator Pond site are from utility wares, particularly rim and body sherds with various incised or punctated decorative elements (Table 2). Only $10.4 \%$ of the decorated sherds have brushed rim and/or body decorations.

Fine wares are relatively common (29.3\% of the decorated sherds) at the site (Table 2$)$. The fine ware vessels used at the Alligator Pond site are about equally divided between sherds with a red slip (on one or both sherd surfaces, either from bowls or carinated bowls) and bowls, carinated bowls, and bottle sherds with simple geometric engraved elements (see also Perttula and Thacker 2013:Table 1).

\section{LITHIC ARTIFACTS}

Lithic artifacts are relatively abundant in the artifact assemblage at the Alligator Pond site, especially lithic debris, cores, and a range of chipped and ground stone tools (Table 3). About $38 \%$ of the chipped stone tools are made on non-local cherts or novaculite; there is a similar proportion of non-local raw materials in the lithic debris, but only $6 \%$ of the cores are on non-local raw materials. 
Table 1. Caddo ceramic sherd assemblage from the Alligator Pond site.

\begin{tabular}{lrr}
\hline Artifact class & No. & Percent \\
\hline Plain ware & 2211 & 85.5 \\
Plain rim & 32 & 1.2 \\
Plain body & 2061 & 79.7 \\
Plain base & 118 & 4.6 \\
& & \\
Utility ware & 266 & 10.3 \\
Utility ware rim & 29 & 1.1 \\
Utility body & 237 & 9.2 \\
& & 4.2 \\
Fine ware & 110 & 0.2 \\
Fine ware rim & 5 & 4.0 \\
Fine ware body & 105 & 100.0 \\
\hline Totals & 2587 & \\
\hline
\end{tabular}

Table 2. Decorated sherds from the Alligator Pond site.

\begin{tabular}{lrr}
\hline Decorative Method & No. & Percent \\
\hline Utility ware & 7 & \\
Appliqued & 32 & 1.9 \\
Brushed & 3 & 8.5 \\
Brushed-incised & 4 & 0.8 \\
Brushed-punctated & 128 & 1.1 \\
Incised & 14 & 34.0 \\
Incised-punctated & 1 & 3.7 \\
Lip notched & 1 & 0.3 \\
Pinched & 76 & 0.3 \\
Punctated & 266 & 20.2 \\
$\quad$ Subtotal & & 70.7 \\
$\quad$ Fine ware & & \\
Red-slipped & 51 & 13.6 \\
Engraved $\quad 59$ & 15.7 \\
$\quad$ Subtotal & 110 & 29.3 \\
\hline Totals & 376 & 100.0 \\
\hline
\end{tabular}


Table 3. Lithic artifact assemblage from the Alligator Pond site.

\begin{tabular}{lrc}
\hline Artifact class & No. & Percent \\
\hline Dart points & 26 & 2.5 \\
Biface preforms and fragments & 11 & 1.1 \\
Bifacial knives/tools & 2 & 0.2 \\
Arrow points & 26 & 2.5 \\
Flake tools & 25 & 2.4 \\
Lithic Debris & 841 & 82.6 \\
Cores & 48 & 4.7 \\
Celt & 1 & 0.1 \\
Ground stone tools & 24 & 2.3 \\
Fire-cracked rock & 14 & 1.3 \\
\hline Totals & 1018 & 100.0 \\
\hline
\end{tabular}

There is a wide range of projectile points in the Alligator Pond artifact assemblage (Table 4). Dart points considered to be of Woodland period age - including cf. Darl, Ellis, Gary, Godley, and Kent forms - represent $46 \%$ of the entire dart point sample and $57 \%$ of the points that can be identified to type. Most of the other dart points represent a Late Archaic use-Bulverde, Morrill, Williams, and Yarbrough types-except for one Johnson point (dating ca. 6000 B.P. in the Middle Archaic) made from a gray novaculite and a side-notched point made from local quartzite.

Table 4. Projectile points from the Alligator Pond site.

\section{Dart points}

Bulverde

cf. Darl 3.8

Ellis

$\begin{array}{ll}1 & 3.8\end{array}$

Gary

Godley

Johnson

Kent

Morrill

Williams

$\begin{array}{ll}8 & 30.8\end{array}$

Yarbrough

$1-3.8$

$\begin{array}{ll}1 & 3.8\end{array}$

$\begin{array}{ll}1 & 3.8\end{array}$

$\begin{array}{ll}1 & 3.8\end{array}$

$\begin{array}{ll}2 & 7.7\end{array}$

$4 \quad 15.4$

$\begin{array}{lcc}\text { Unidentified forms } & 2 & 7.7\end{array}$

$\begin{array}{lrr}\text { Fragments } & 3 & 11.5\end{array}$

$\begin{array}{lrr}\text { Subtotal } & 26 & 100.0\end{array}$


Table 4. Projectile points from the Alligator Pond site, cont.

\begin{tabular}{lcr}
\hline Arrow points & & \\
\hline Alba & 5 & 19.2 \\
Bassett & 1 & 3.8 \\
Bonham & 1 & 3.8 \\
Catahoula & 1 & 3.8 \\
Perdiz & 3 & 11.5 \\
Scallorn and/or Homan & 3 & 11.5 \\
Steiner & 2 & 7.7 \\
Preforms & & 15.4 \\
Fragments $\quad$ Subtotal & 6 & 23.1 \\
\multicolumn{1}{c}{} & 26 & \\
\hline
\end{tabular}

The stemmed arrow points in the Alligator Pond artifact assemblage appear to reflect both pre- and postA.D. 1200 Caddo use. The earlier forms - Alba, Catahoula, Scallorn and/or Homan, and Steiner-comprise $69 \%$ of the arrow points that can be identified to type, while the post-A.D. 1200 Bassett, Bonham, and Perdiz points ( $31 \%$ of the points identified to type) suggest some use of the site as late as the $15^{\text {th }}$ century A.D.

\section{HISTORIC ARTIFACTS}

This third collection from the Alligator Pond site has a single plain whiteware rim sherd that may be associated with the small early $19^{\text {th }}$ century historic component there (see Perttula and Thacker 2013).

\section{SUMMARY AND CONCLUSIONS}

The Alligator Pond site (41SM442) is situated on an upland ridge in the Saline Creek valley. It has been repeatedly used by aboriginal peoples from as early as ca. 6000 years B.P. until perhaps the $15^{\text {th }}$ century A.D. There is also a sparse early $19^{\text {th }}$ century component that may be associated with an early Anglo-American settlement of the region; however, if this component represents a pre-1830 occupation, it may mark a habitation site occupied by a Native American group such as the Caddo, whose traditional homelands these were, or the Cherokee, who had immigrated to the area by 1820 .

The most substantial and/or intensive aboriginal occupations of the Alligator Pond site took place first during the latter part of the Woodland period (after ca. A.D. 200). This component is marked principally by contracting stem Gary dart points and plain sandy paste ceramic sherds. A later, and principal aboriginal, occupation was by Caddo peoples sometime between ca. A.D. 1000-1300. This occupation was clearly that of a domestic settlement by one or more Caddo families who would have lived in a sturdy wood and thatch house, and their indoor and extra mural use of ceramic vessels for the cooking and serving of food stuffs and liquids, as well as the storage of foods, and their eventual breakage, left a substantial assemblage of sherds from plain ware, utility ware, and fine ware vessels. 


\section{REFERENCES CITED}

Perttula, T. K. and M. Thacker

2013 Analysis of New Artifact Collections from Archaic to Ancestral Caddo Sites in the Saline Creek Basin in Northern Smith County, Texas. Journal of Northeast Texas Archaeology 43:1-25.

Perttula, T. K. and M. Walters

2012 Caddo Sites in the Saline Creek Basin in Northern Smith County, Texas. Journal of Northeast Texas Archaeology 36:47-63. 